\title{
Significantly Lower Serum Adiponectin Levels in the Postmenopausal Age may be Specific for Breast Cancer Risk
}

\author{
Postmenopozal Meme Kanserinde Anlamlı Düşük Serum Adiponektin Düzeyleri
}

\author{
(D) Turgut Aksoy1, (1) Didem Can Trabulus2, (1) Hale Aral33, (1) Erdinç Serin"4, (D) Canan Kelten Talu5 \\ ${ }^{1}$ Bezmialem Vakıf University Faculty of Medicine, Department of Medical Biochemistry, İstanbul, Turkey \\ 2University of Health Sciences Turkey, İstanbul Training and Research Hospital, Clinic of General Surgery, İstanbul, Turkey \\ 3University of Health Sciences Turkey, İstanbul Training and Research Hospital, Clinic of Medical Biochemistry Laboratory, İstanbul, Turkey \\ 4 istanbul Șișli Hamidiye Eftal Training and Research Hospital, Clinic of Medical Biochemistry Laboratory, İstanbul, Turkey \\ 5 University of Health Sciences Turkey, İstanbul Training and Research Hospital, Clinic of Clinical Pathology Laboratory, İstanbul, Turkey
}

\begin{abstract}
Introduction: To date, biomarkers have played a minimal role in the early diagnosis of breast cancer. Although its effects on metabolism are not well known, studies have shown that hypoadiponectinaemia is associated with increased insulin resistance and risk for type-2 diabetes. We aimed to investigate the value of adiponectin together with laboratory results, anthropometric measurements and histopathological findings in assessing the risk of breast cancer and for use in early diagnosis.
\end{abstract}

Methods: In this study, serum samples were obtained from 59 recently diagnosed breast cancer patients and 47 cancerfree controls aged between 22 and 82 years to assay serum adiponectin, lipids, fasting blood glucose and insulin; homeostatic model assessment for insulin resistance (HOMA-IR) and body mass index were calculated using the anthropometric measurements. Histopathologic findings were extracted from the patients' files.

Results: Our results revealed that adiponectin serum levels and HOMA-IR values were significantly different between patients and controls. In addition, serum adiponectin levels were lower in postmenopausal breast cancer patients compared to the controls $(p=0.03)$.

Conclusion: In fact, a serum adiponectin level below $4.46 \mathrm{mg} / \mathrm{L}$ may be in favour of postmenopausal breast cancer (area under the curve $=70 \%$ ). However, Cerb-B2 expression in patients did not correlate with serum adiponectin levels. These findings have implications for further research on adiponectin as well as the in early diagnosis of postmenopausal breast cancer with possibly higher test sensitivity.

Keywords: Adiponectin, insulin resistance, early diagnosis of breast cancer, body mass index, serum lipids

\section{öz}

Amaç: Meme kanseri erken tanısında, serum biyomarker düzeyleri kullanımı sınırlı kalmaktadır. Metabolizması tam olarak bilinmese de, hipoadiponektinemi ile artmış insülin direnci ve tip II diyabet riski arasında ilişkili olduğu gösterilmiștir. Bu çalışmada, serum adiponektin düzeylerinin antropometrik ölçümler ve diğer laboratuvar bulgularıyla birlikte meme kanseri tanısındaki klinik yararını araștırmayı amaçladık.

Yöntemler: Çalışmamızda 22-82 yaș arası kadınlarda meme kanseri hastası ( $\mathrm{N}=59)$ ve kontrol grubunu oluşturan sağlıklı bireylerden $(\mathrm{N}=47)$ alınan kan örneklerinde adiponektin, lipidler, açlık kan şekeri ve insülin düzeyleri ölçüldü ve insülin direnci için homeostatik model değerlendirmesi (HOMA-IR), vücut kitle indeksi hesaplandı. Histopatolojik veriler hasta dosyalarından elde edildi. Anamnez, folikül uyarıcı hormon ve luteinleştirici hormon düzeylerine göre hastalar premenapoz ve postmenapoz olarak sınıflandırıldı.

Bulgular: Sonuçlarda, meme kanseri hastalarının adiponektin ve HOMA-IR düzeyleri ile kontrol grubununkiler arasında anlamlı fark görülmüștür. Ayrıca postmenopozal hastaların serum adiponektin düzeyleri kontrollere göre anlamlı düșük bulunmuştur ( $p=0,03)$.

Sonuç: Aynı zamanda, 4,46 mg/L altındaki serum adiponektin düzeyleri, postmenopozal meme kanserine spesifite göstermektedir (eğri altındaki alan =\%70). Ancak, Cerb-B2 ekspresyonu adiponektin ile korele bulunmamıştır. Bu sonuçlara göre, daha çok örnekle özellikle postmenopozal grupta yapılacak çalışmalar, adiponektinin erken tanıda daha yüksek hassasiyete sahip olduğunu ortaya çıkarabilir ve bu amaçla kullanılmasını destekleyecek sonuçlar verebilir.

Anahtar Kelimeler: Adiponektin, insülin direnci, meme kanserinde erken tanı, vücut kitle indeksi, lipidler
Address for Correspondence/Yazıșma Adresi: Turgut Aksoy MD, Bezmialem Vakıf University Faculty of Medicine, Department of Medical Biochemistry, ístanbul, Turkey

Phone: +90 5332209118 E-mail: turgutaksoy@hotmail.com ORCID ID: orcid.org/0000-0001-5041-0364

Cite this article as/Atıf: Aksoy T, Can Trabulus D, Aral H, Serin E, Kelten Talu C. Significantly Lower Serum Adiponectin Levels in the Postmenopausal Age may be Specific for Breast Cancer Risk. İstanbul Med J 2020; 21(5): 355-61.
Received/Geliş Tarihi: 18.10.2019 Accepted/Kabul Tarihi: 08.07.2020

(C) Copyright 2020 by the University of Health Sciences Turkey, Istanbul Training and Research Hospital/istanbul Medical Journal published by Galenos Publishing House.

(C) Telif Hakkı 2020 Sağıı Bilimleri Üniversitesi Istanbul Ĕgitim ve Araştırma Hastanesi/Istanbul Tıp Dergisi, Galenos Yayınevi tarafından basılmıștır. 


\section{Introduction}

Breast cancer is the most common type of cancer among women. It is estimated that over 627,000 women died of breast cancer in 2018 worldwide (1). Also, the incidence rates vary greatly worldwide (2).

Danaei et al. (3) calculated the contribution of modifiable risk factors for breast cancer and concluded that $21 \%$ of all breast cancer deaths are attributable to obesity/overweight and physical inactivity together with alcohol use.

Adiponectin, a 30kD peptide discovered in 1995 by Scherer et al. (4), is secreted in adipose tissue. It is found in lower levels in patients diagnosed with obesity-associated cancers and its synthesis is inhibited in obese subjects. Plasma adiponectin concentrations are inversely correlated with body mass index (BMI) (5). Adiponectin has insulin-sensitising, antiinflammatory, anti-atherogenic, anti-neoplastic and cardioprotective effects (6). It has been shown to inhibit the proliferation of several cancer-derived cells including breast, endometrium, prostate and colorectal cancer. Surprisingly, it exhibits both pro and anti-angiogenic characteristics. Adiponectin acts indirectly by modulating insulin sensitivity in the breast epithelium, influencing tumour angiogenesis and regulating the inflammatory responses (6).

Hypoadiponectinaemia, which is the result of both genetic and/ or environmental factors, is associated with several disorders like insulin resistance, diabetes mellitus type-2, hypertension and several malignancies (7). Specifically, low adiponectin levels promote fatty acid and protein synthesis, as well as cell growth and proliferation (8).

Most studies showed significantly low adiponectin levels in breast cancer patients compared to healthy controls. While some of these studies found no relationship at all, others found even higher adiponectin levels in patients compared to controls. On the other hand, a study by Karaduman et al. (9), showed significantly higher levels of adiponectin in breast tumour tissue compared to the control group. There is evidence that a higher ratio of leptin, another adipokin, to adiponectin may be a sign of the presence of aggressive breast cancers (10).

The objective of this study was to assess serum levels of adiponectin in breast cancer patients and healthy controls with respect to the menopausal status and indicators of obesity, BMI and interventional radiology. We also aimed to investigate the relationship between serum adiponectin levels and histopathological tissue Cerb-B2 receptor status.

\section{Methods}

This study was conducted in compliance with the Good Clinical Practice guidelines and the ethical principles stated in the Declaration of Helsinki, and was approved by the Ethical Committee of University of Health Sciences Turkey, İstanbul Training and Research Hospital under report numbered 469. Sixty-eight women with signs of breast cancer who had been treated in the Surgery Department of University of Health Sciences Turkey, İstanbul Training and Research Hospital between February 2012 and February 2013 were enrolled into our study. All the patients gave written consent to participate in the study. Nine of them were excluded either because they were misdiagnosed or laboratory results were inconsistent. Breast cancer diagnosis was based on biopsy results. Serum samples after 8 hours of fasting had been obtained from the patients during their stay in the hospital. Demographic data of the patients were obtained from the patients' file. Weight, height and waist circumference were measured at the time of blood withdrawal. Blood tests ordered by the physician were ran and serum samples were later stored at $-80^{\circ} \mathrm{C}$.

Forty-seven healthy women, without known breast cancer confirmed by mammo-ultrasonography, comprised our control group. Serum samples were collected in the ambulatory clinic and later frozen until analysis.

Exclusion criteria for the patient group were as follows:

1. Patients already diagnosed with malignant disease other than breast cancer

2. Patients who received any form of cancer therapy (surgery, radiotherapy, chemotherapy)

3. Biopsy result rejected the diagnosis of breast cancer

A total of 59 patient and 47 control samples were defrosted and in turn ran using the Human Adiponectin ELISA (Hangzhou Eastbiopharm Co. Ltd.) on June the same year (Cat. No: CK-E10871). Reference ranges for women were defined as 2-30 mg/L, with an analytical range of $0.2-$ $60 \mathrm{mg} / \mathrm{L}$ and LoD of $0.11 \mathrm{mg} / \mathrm{L}$. Insulin levels were measured by the ECLIA method using DXI 800 (Beckman-Coulter Inc., USA). Fasting serum glucose (FSG), total cholesterol, triglyceride, high density lipoproteincholesterol (HDL-C) and low density lipoprotein-cholesterol (LDL-C) levels were measured by photometric method using commercial reagents on AU 2700 (Beckman-Coulter Inc., USA). Menopausal statuses of the patients were determined by combining the data of age at diagnosis, FSH and luteinizing hormone measurements or menstruation history in the patient records.

Insulin resistance was calculated as homeostatic model assessment for insulin Resistance (HOMA-IR) using formula:

$$
\text { HOMA-IR= }=\frac{\text { Glucose }(\mathrm{mg} / \mathrm{dL}) \times \operatorname{Insulin}(\mathrm{mU} / \mathrm{L})}{405}
$$

BMI was calculated based on the following formula: bodyweight in kilograms divided by height in metres squared.

CerbB2 immunostaining pattern was noted as a score of 0, 1, 2 and 3; cases with score 0 and 1 were accepted as negative for overexpression. Cases with score 3 alone and score 2, but with verified positivity for overexpression by an in situ hybridisation method were accepted as positive.

\section{Statistical Analysis}

Statistical data was analysed using SPSS 15.0 for Windows. For comparing two independent groups, Student t-test was used for normally distributed variables and Mann-Whitney $U$ for non-Gaussian distributed variables. For comparing more than two independent groups, One-Way ANOVA test was used for normally distributed variables and KruskalWallis test for non-Gaussian variables. Sub-group analyses were performed using Tukey's test for parametric and Mann-Whitney U test 
for non-parametric tests and Bonferroni correction was implemented. The Spearman Correlation method was used for non-parametric tests. Factors that increase the risk for breast cancer were evaluated using Logistic Regression Forward method. For all comparisons, a level of $p<0.05$ was considered statistically significant.

\section{Results}

Demographic and laboratory data were compared in Table 1. Adiponectin but not HOMA-IR was found to be significantly lower in the patient group compared to the control group $(p=0.020$; Table 1, Figures $1,2)$. Neither HOMA-IR nor adiponectin proved to be correlated with any of the parameters shown on Table 2 in the patient and control groups ( $p=0.061, p=0.468)$. HOMA-IR was positively correlated with FSG, insulin and $\mathrm{BMI}$ in the patient group and age, FSG, insulin, triglyceride and BMI in the control group (Table 2).

Adiponectin was significantly lower in the premenopausal group compared to the postmenopausal group ( $p=0.015)$. We evaluated the groups with respect to the menopausal status, comparing adiponectin

Table 1. Demographic information and biochemical parameters of the patient and control groups

\begin{tabular}{|l|l|l|l|}
\hline & Patients $(\mathbf{n}=59)$ & Controls $(\mathbf{n = 4 7})$ & \\
\hline & Mean \pm SD & Mean \pm SD & $\mathbf{p}$ \\
\hline Age (year) & $52.49 \pm 13.81$ & $49.91 \pm 9.76$ & 0.267 \\
\hline BMI (kg/m²) & $27.92 \pm 5.45$ & $28.46 \pm 4.45$ & 0.277 \\
\hline FSG (mg/dL) & $110.81 \pm 43.42$ & $94.0 \pm 8.98$ & 0.096 \\
\hline Insulin(mU/L) & $7.02 \pm 5.11$ & $9.21 \pm 5.27$ & 0.008 \\
\hline Total cholesterol (mg/dL) & $209.75 \pm 43.77$ & $220.91 \pm 47.84$ & 0.214 \\
\hline Triglyceride (mg/dL) & $131.36 \pm 74.75$ & $120.49 \pm 50.75$ & 0.834 \\
\hline HDL-C (mg/dL) & $53.32 \pm 15.76$ & $59.84 \pm 14.88$ & 0.023 \\
\hline LDL-C (mg/dL) & $131.64 \pm 40.72$ & $136.89 \pm 39.82$ & 0.288 \\
\hline Adiponectin (mg/L) & $5.18 \pm 2.61$ & $6.45 \pm 3.94$ & 0.020 \\
\hline HOMA-IR & $1.99 \pm 1.72$ & $2.17 \pm 1.32$ & 0.131 \\
\hline
\end{tabular}

FSG: Fasting serum glucose, BMI: body mass index, HDL-C: high density lipoproteincholesterol, LDL-C: low density lipoprotein-cholesterol, HOMA-IR: homeostatic model assessment for insulin resistance, SD: standard deviation

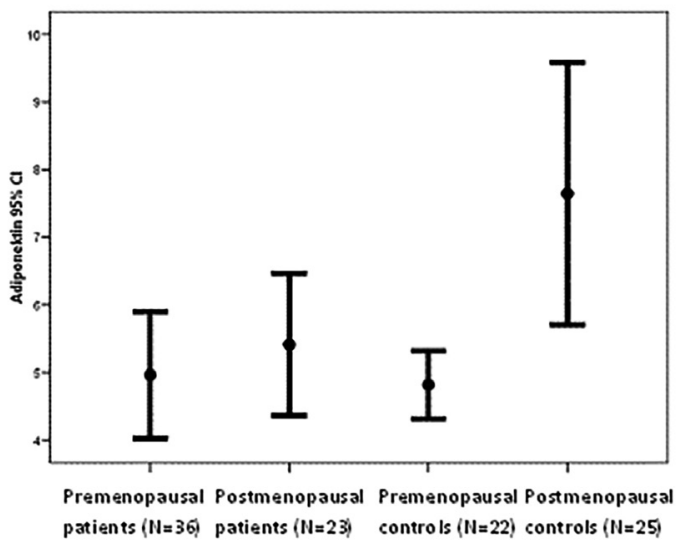

Figure 1. Plot graph showing distribution of serum adiponectin levels through sub-groups according to menapausal status, $\mathrm{N}_{\text {patients }}=59 ; \mathrm{N}_{\text {controls }}=47$ Cl: Confidence interval and BMI values. In the patient group, BMI was significantly higher in the postmenopausal group compared to the premenopausal group $(p=0.008$; Figure 3, Table 3).

\section{Discussion}

Current research on breast cancer, mainly focuses on early diagnosis, treatment and detection of relapses. Early diagnosis in breast cancer is life-saving and significant for public health.

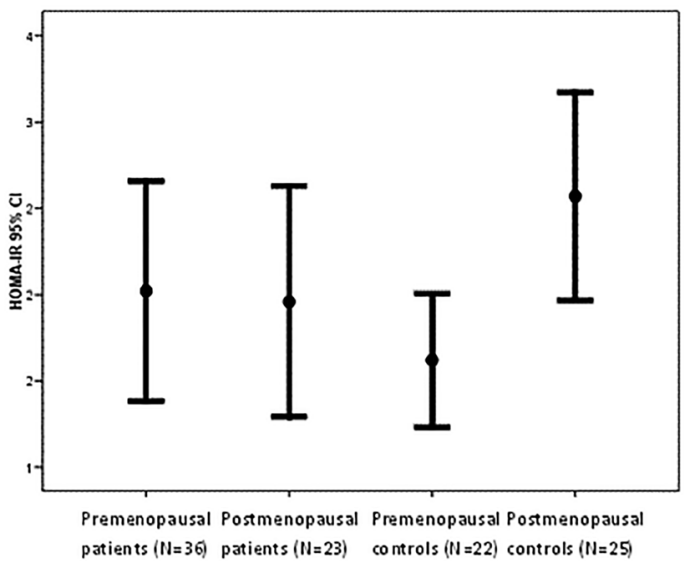

Figure 2. Plot graph showing distribution of HOMA-IR values $\mathrm{N}_{\text {patients }}=59$; $\mathrm{N}_{\text {controls }}=47$

HOMA-IR: Homeostatic model assessment for insulin resistance, Cl: confidence interval

Table 2. Correlation of studied parameters with adiponectin and HOMA-IR values in the patient and control groups

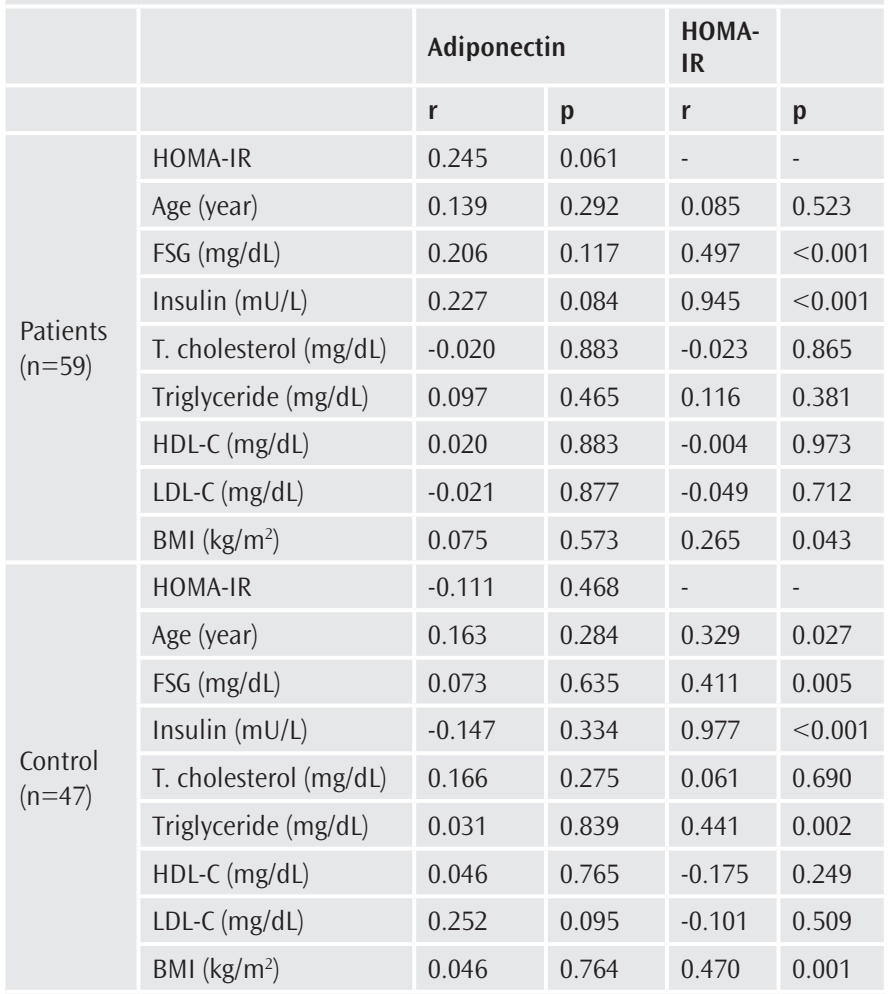

T.cholesterol: Total cholesterol, FSG: fasting serum glucose, BMI: body mass index, HDL-C: high density lipoprotein-cholesterol, LDL-C: low density lipoprotein-cholesterol, HOMA-IR: homeostatic model assessment for insulin resistance 
Adiponectin but not HOMA-IR was found to be lower in the patients compared to controls ( $p=0.020$; Table 1). This finding has actually been proven in several studies up-to-today (11-13), and was a result that we expected.

Previous studies have shown that BMI values are associated with postmenopausal breast cancer risk. In fact, Ahn et al. (14) hypothesised that weight gain during the adult life is associated with increased risk for postmenopausal breast cancer. More recent studies have also shown a significant increase in breast cancer risk after weight gain (15), especially in postmenopausal women $(16,17)$. In our study; however, we found no significantly high BMI values in the postmenopausal patients compared to controls ( $p=0.822$; Table 3 ).

Triglyceride levels in the controls seem to be correlated with HOMA-IR; however, in the patient group they were discordant. HOMA-IR was well correlated with BMI in both groups (Tables 2, 4).

There was a prominent difference in BMI values between the preand postmenopausal groups, which may result from the significant difference in age between these groups (Table 3).

Studies show some disorders associated with adiponectin such as obesity and insulin resistance $(13,18,19)$. BMI, used widely as a measure

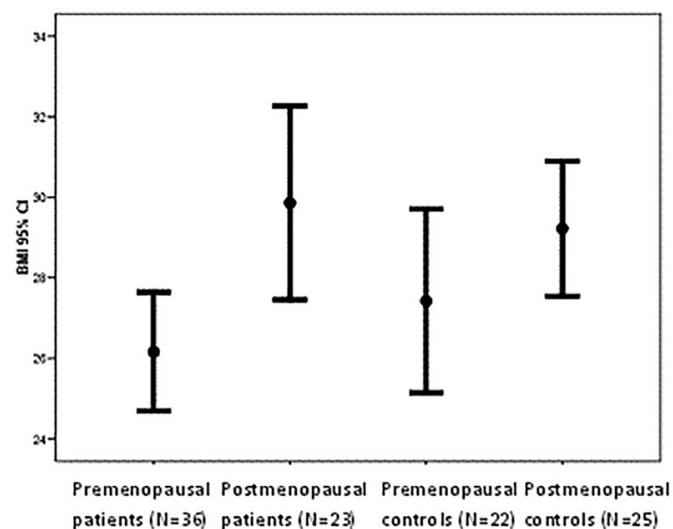

Figure 3. Plot graph of BMI values, Npatients $=59$; Ncontrols $=47$ BMI: Body mass index, $\mathrm{Cl}$ : confidence interval of obesity, is well documented $(6,13)$. Low levels of serum adiponectin and increased insulin resistance together with increased BMI have already been shown in breast cancer patients in some studies $(13,20,21)$. However, none of the parameters investigated in our study including BMI and HOMA-IR was found to be correlated with adiponectin (Table 4).

Körner et al. (12) have also concluded that adiponectin levels in breast cancer patients were lower irrespective of age, BMI, parity, insulin or family history. When we specifically consider the postmenopausal group, adiponectin levels were lower in the patients. In fact, in this group, we found that lower serum adiponectin and higher age are risk factors for postmenopausal breast cancer (Table 5).

Another surprising result in the postmenopausal group was that HOMAIR values were significantly lower in the patients $(p=0.016$; Table 5$)$.

In a review of a prospective study conducted by Endogenous Hormones and Breast cancer Collaborative Group (Key et al.) (22), relative risk (RR) for breast cancer was calculated in postmenopausal women with respect

\begin{tabular}{|c|c|c|c|}
\hline & $\begin{array}{l}\text { Premenopausal } \\
(n=52)\end{array}$ & $\begin{array}{l}\text { Postmenopausal } \\
(\mathrm{n}=54)\end{array}$ & \\
\hline \multirow[t]{3}{*}{ Adiponectin (mg/L) } & \multirow[t]{3}{*}{$4.91 \pm 2.09$} & $6.49 \pm 3.99$ & 0.015 \\
\hline & & Adiponectin & BMI \\
\hline & & $p$ & p \\
\hline \multirow{3}{*}{$\begin{array}{l}\text { Premenopausal } \\
\text { patient }\end{array}$} & $\begin{array}{l}\text { Postmenopausal } \\
\text { patient }\end{array}$ & 0.642 & 0.008 \\
\hline & $\begin{array}{l}\text { Premenopausal } \\
\text { control }\end{array}$ & 0.830 & 0.358 \\
\hline & $\begin{array}{l}\text { Postmenopausal } \\
\text { control }\end{array}$ & 0.006 & 0.015 \\
\hline \multirow{2}{*}{$\begin{array}{l}\text { Postmenopausal } \\
\text { patient }\end{array}$} & $\begin{array}{l}\text { Premenopausal } \\
\text { control }\end{array}$ & 0.997 & 0.329 \\
\hline & $\begin{array}{l}\text { Postmenopausal } \\
\text { control }\end{array}$ & 0.143 & 0.822 \\
\hline $\begin{array}{l}\text { Premenopausal } \\
\text { control }\end{array}$ & $\begin{array}{l}\text { Postmenopausal } \\
\text { control }\end{array}$ & 0.147 & 0.115 \\
\hline
\end{tabular}

Table 4. Correlation of adiponectin with body mass index in the postmenopausal group

\section{Correlations}

\begin{tabular}{|c|c|c|c|c|c|}
\hline & & & BMI & IR & Adiponectin \\
\hline \multirow{6}{*}{ Spearman's rho } & \multirow[b]{2}{*}{ BMI } & Correlation coefficient & 1.000 & $0.421^{* *}$ & 0.010 \\
\hline & & Sig. (2-tailed) & - & 0.003 & 0.945 \\
\hline & \multirow[b]{2}{*}{ IR } & Correlation coefficient & $0.421^{* *}$ & 1.000 & 0.037 \\
\hline & & Sig. (2-tailed) & 0.003 & - & 0.804 \\
\hline & \multirow[t]{2}{*}{ Adiponectin } & Sig. (2-tailed) & 0.945 & 0.804 & - \\
\hline & & $\mathrm{N}$ & 48 & 48 & 48 \\
\hline
\end{tabular}


to BMI tertiles. In addition to oestradiol, some other steroid hormones and sex hormone binding globulin (SHBG) have also been assayed (23). Calculating RR adjusting for the results of these tests yielded less significant increased risk in the high-BMI group. This raises the idea that oestrogens might play a major role in postmenopausal breast cancer risk rather than obesity.

To investigate the difference in adiponectin serum levels between patients and controls, we set three intervals for adiponectin concentration to see if there was a significant trend toward patients in the low adiponectin group. However, this did not yield a significant difference between the groups (Table 6; $p<0.325$ ).

Histopathologic Cerb-B2 expression in breast cancer patients was not associated with serum adiponectin-to-BMI ratio. Cubukcu et al. (24) found no associations between adiponectin histochemical expression and prognosis. Karaduman et al. (9) also conducted similar research with tissue adiponectin levels to find similar results in Turkish population. Our results are one of the very few of its kind in a Turkish population (Table 7).

For the postmenopausal group, the difference in adiponectin levels between patients and controls was more significant. Therefore, we calculated the area under the curve (AUC) for breast cancer risk and adiponectin levels; a concentration below $4.46 \mathrm{mg} / \mathrm{L}$ had $70 \%$ AUC, 80\% specificity and $52 \%$ sensitivity for breast cancer. We wanted this test to have a high sensitivity at maximum AUC. However, it was quite low. This is only a preliminary model and we believe that this study could provide more reliable outcome for clinical use if it will be repeated with higher number of samples (Figure 4).
A review on use of adiponectin as a routine clinical biomarker, suggests that hypoadiponectinemia, a serum level of $<4 \mathrm{mg} / \mathrm{L}$, is associated with several diseases including postmenopausal breast cancer, although not specifically (19). A recent meta-analysis concludes that pre and postmenopausal breast cancer patients have significantly lower serum adiponectin levels compared to controls and that adiponectin may serve as a biomarker of breast cancer risk and help to identify subjects at high risk for breast cancer development (25).

We found no significant difference in triglyceride levels between the patient and control groups, which is in line with the results of a recent meta-analysis (26). A cohort study of 3537 cases showed relatively lower HDL-C, LDL-C and total cholesterol levels in breast cancer patients with age stratification. LDL-C and total cholesterol levels were still lower in the patient group compared to the controls (27). In our study, HDL-C levels were lower in the patient group compared to the controls. However LDL-C levels did not show a significant difference.

A drawback of our study was that it lacked serum levels of oestradiol, SHBG and other steroid hormones. For this reason, it is challenging to tell if the increase in breast cancer risk associated with increasing BMI values was a result of the oestradiol levels.

The second drawback of the study was the lack of parity data. Increased parity has been reported to be associated with increased breast cancer risk. We also did not collected data on age at menarche, age at menopause and age at first labour. Finally, the difference in age between postmenopausal patients and controls might be a reason for the significant difference in adiponectin (Table 5).

\begin{tabular}{|c|c|c|c|c|c|c|c|c|c|}
\hline & BMI & Age & TG & TC & HDL & LDL & FSG & HOMA-IR & Adiponectin \\
\hline Z & -0.341 & -4.163 & -0.898 & -0.237 & -1.239 & -0.527 & -1.591 & -2.404 & -2.322 \\
\hline OR & - & $1.206(1.07-1.35)$ & - & - & - & - & - & $\begin{array}{l}0.843 \\
(0.49-1.44)\end{array}$ & $\begin{array}{l}0.755 \\
(0.59-0.97)\end{array}$ \\
\hline
\end{tabular}

TC: Total cholesterol, FSG: fasting serum glucose, BMI: body mass index, HDL: high density lipoprotein, LDL: Iow density lipoprotein, HOMA-IR: homeostatic model assessment for insulin resistance, OR: odds ratio, TG: triglyceride

Table 6. Distribution of the patient and control groups by adiponectin levels

\begin{tabular}{|c|c|c|c|c|c|c|}
\hline & \multirow{2}{*}{\multicolumn{2}{|c|}{ Patient }} & & & & \\
\hline & & & \multicolumn{2}{|c|}{ Control } & & \\
\hline & $n$ & $\%$ of row & $n$ & $\%$ of row & $\mathrm{p}$ & \\
\hline \multirow[t]{2}{*}{ Adiponectin } & $6-8.9$ & 8 & 72.7 & 3 & 27.3 & - \\
\hline & 9 and above & 6 & 42.9 & 8 & 57.1 & - \\
\hline
\end{tabular}

Table 7. Comparison of serum adiponectin/body mass index $\left(\mathrm{mg} \cdot \mathrm{m}^{2} / \mathrm{kg} \cdot \mathrm{L}\right)$ levels in sub-groups of breast cancer classified according to histopathological examination of CerbB2 immunostaining pattern, $\mathrm{N}_{\text {patients }}=52$

Adiponectin/BMI $\left(\mathrm{mg} \cdot \mathrm{m}^{2} / \mathrm{kg} \cdot \mathrm{L}\right)$

BMI: Body mass index
CerbB2 negative $(\mathrm{N}=42)$

$0.149(0.127-0.210)$
CerbB2 positive $(\mathrm{N}=10)$

$0.174(0.138-0.250)$ p

0.390 


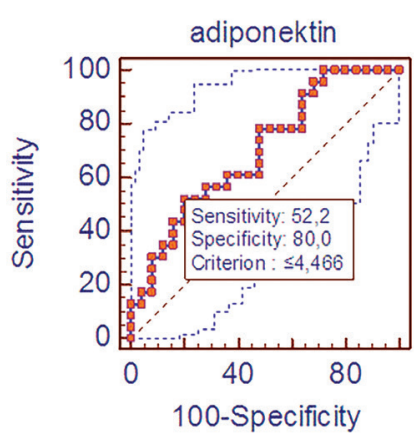

Figure 4. Plot of serum adiponectin levels in postmenopausal group, $\mathrm{N}_{\text {patients }}=23 ; \mathrm{N}_{\text {controls }}=25$ (AUC: $\left.70 \%\right)$

AUC: Area under the curve

\section{Conclusion}

The postmenopausal patients showed significantly lower levels of serum adiponectin than the controls (Figure 1, Table 5). Our results also support previous studies that this significant difference exists irrespective of BMI (Table 4). Although the number of samples was not sufficient, we calculated a serum adiponectin level of $4.6 \mathrm{mg} / \mathrm{L}$, below which postmenopausal cases would be more likely to have breast cancer, and this model provided a reasonable AUC with great specificity. However, the sensitivity of this model was quite low (Figure 4).

Although breast cancer has been shown in several studies to be an obesity-related disease $(7,8,11)$, our study found no significant correlation with HOMA-IR, BMI or with any of the other parameters. Values of HOMA-IR and BMI were not found to be higher in the patient group compared to the controls (Table 7); in fact, patients had lower HOMA-IR compared to controls in the postmenopausal group. Cerb-B2 expression was not associated with serum adiponectin.

We concluded that lower adiponectin and higher age at diagnosis are risk factors for postmenopausal breast cancer. Although an analysis by comparing the tertiles of adiponectin against the patient and control groups yielded no significant difference, a level of serum adiponectin below $4.46 \mathrm{mg} / \mathrm{L}$ may be associated with breast cancer risk. We think that if parameters like waist circumference, serum oestradiol level, parity, age at menarche, age at first labour, including histological and imaging findings (magnetic resonance, mammography, ultrasonography, positron emission tomography, etc) are properly evaluated with a larger sample size, more distinctive results may be achieved, fortifying the value of serum adiponectin levels in the early diagnosis of breast cancer.

\section{Ethics}

Ethics Committee Approval: This study was conducted in compliance with the Good Clinical Practice guidelines and the ethical principles stated in the Declaration of Helsinki, and was approved by the ethical committee of University of Health Sciences Turkey, İstanbul Training and Research Hospital under report numbered 469.

Informed Consent: All the patients gave written consent to participate in the study.

Peer-review: Externally and internally peer-reviewed.
Authorship Contributions: Surgical and Medical Practices - D.C.T.; Concept - T.A.; Design - H.A., T.A.; Data Collection or Processing - D.C.T., C.K.T.; Analysis or Interpretation - T.A., E.S., C.K.T.; Literature Search T.A.; Writing - T.A.

Conflict of Interest: No conflict of interest was declared by the authors.

Financial Disclosure: Grant support on ELISA reagents by University of Health Sciences Turkey, İstanbul Training and Research Hospital.

\section{References}

1. WHO incidence. [Online] Available from: URL: https://www.who.int/cancer/ prevention/diagnosis-screening/breast-cancer/en/.

2. GLOBOCAN 2008. [Online] Available from URL: https://www.iarc.fr/wpcontent/uploads/2018/07/GLOBOCAN2008.pdf.

3. Danaei G, Vander Hoorn S, Lopez AD, Murray CJ, Ezzati M, Comparative risk assessment collaborating group (Cancers). Causes of cancer in the world: comparative risk assessment of nine behavioural and environmental risk factors Lancet 2005; 366; 1784-93.

4. Scherer PE, Williams S, Fogliano M, Baldini G, Lodish HF. A novel serum protein similar to Clq, produced exclusively in adipocytes. J Biol Chem 1995; 270: 26746-9.

5. Vona-Davis L, Rose DP. Angiogenesis, adipokines and breast cancer. Cytokine Growth Factor Rev 2009; 20: 193-201.

6. Dalamaga M. Obesity, insulin resistance, adipocytokines and breast cancer: New biomarkers and attractive therapeutic targets. World J Exp Med 2013; 3: 34-42.

7. Avgerinos K, Spyrou N, Mantzoros C, Dalamaga M. Obesity and Cancer Risk: Emerging biological mechanisms and perspective. Metabolism 2019; 92: 121 35 .

8. Spyrou N., Avgerinos K., Mantzoros C., Dalamaga M. Classic and novel adipocytokines at the intersection of obesity and cancer: diagnostic and therapeutic strategies. Curr Obes Rep 2018; 7: 260-75.

9. Karaduman M, Bilici A, Ozet A, Sengul A, Musabak U, Alomeroglu M. Tissue levels of adiponectin in breast cancer patients. Med Oncol 2007; 24: 361-6.

10. Chen DC, Chung YF, Yeh YT, Chaung HC, Kuo FC, Fu OY, et al. Serum adiponectin and leptin levels in Taiwanese breast cancer patients. Cancer Lett 2006; 237: 109-14

11. Mantzoros C, Petridou E, Dessypris N, Chavelas C, Dalamaga M, Alexe DM, et al. Adiponectin and breast cancer risk. J Clin Endocrinol Metab 2004; 89: 1102-7.

12. Körner A, Pazaitou-Panayiotou K, Kelesidis T, Kelesidis I, Williams CJ, Kaprara A, et al. Total and high-molecular-weight adiponectin in breast cancer: in vitro and in vivo studies. J Clin Endocrinol Metab 2007; 92: 1041-8.

13. Dalamaga M, Diakopoulos KN, Mantzoros CS. The role of adiponectin in cancer. Endocr Rev 2012; 33: 547-94.

14. Ahn J, Schatzkin A, Lacey JV Jr, Albanes D, Ballard-Barbash R, Adams KF, et al. Adiposity, adult weight change, and postmenopausal breast cancer risk. Arch Intern Med 2007; 167: 2091-102.

15. Emaus MJ, van Gils CH, Bakker MJ, Bisschop CNS, Monninkhof EM, de Mesquita $\mathrm{HBB}$, et al. Weight change in middle adulthood and breast cancer risk in the EPIC-PANACEA study. Int J Cancer 2014; 135: 2887-99.

16. Rosner B, Eliassen AH, Toriola AT, Chen WY, Hankinson SE, Willett WC, et al. Weight and weight changes in early adulthood and later breast cancer risk. Int J Cancer 2017; 140: 2003-14.

17. Chen Y, Liu L, Zhou Q, Imam MU, Cai J, Wang Y, et al. Body mass index had different effects on premenopausal and postmenopausal breast cancer 
risks: a dose-response meta-analysis with 3,318,796 subjects from 31 cohort studies. BMC Public Health 2017; 17: 936.

18. Brochu-Gaudreau K, Rehfeldt C, Blouin R, Bordignon V, Murphy BD, Palin MF. Adiponectin action from head to toe. Endocrine 2010; 37: 11-32.

19. Kishida K, Funahashi T, Shimomura I. Adiponectin as a routine clinical biomarker Best Pract Res Clin Endocrinol Metab 2014 ; 28: 119-30

20. Hivert MF, Sullivan LM, Fox CS, Nathan DM, D’Agostino sr RB, Wilson PWF, et al. Associations of adiponectin, resistin, and tumor necrosis factor- $\alpha$ with insulin resistance J Clin Endocrinol Metab 2008; 93: 3165-72.

21. Weyer C, Funahashi T, Tanaka S, Hotta K, Matsuzawa Y, Pratley RE, et al. Hypoadiponectinemia in obesity and type 2 diabetes: close association with insulin resistance and hyperinsulinemia. J Clin Endocrinol Metab 2001; 86: 1930-5.

22. Key TJ, Appleby PN, Reeves GK, Roddam A, Dorgan JF, Longcope C, et al. Body mass index, serum sex hormones, and breast cancer risk in postmenopausal women. J Natl Cancer Inst 2003; 95: 1218-26.
23. Zeleniuch-Jacquotte A, Afanasyeva Y, Kaaks R, Rinaldi S, Scarmo S, Liu M, et al. Premenopausalserum androgens and breast cancer risk: a nested casecontrol study. Breast Cancer Res 2012; 14: R32.

24. Cubukcu E, Olmez F, Kanat O, Kabul S, Canhoroz M, Avci N, et al. Lack of prognostic significance of adiponectin immunohistochemical expression in patients with triple-negative breast cancer Contemp Oncol (Pozn) 2014; 18 : 34-8.

25. Gu L, Cao C, Fu J, Li Q, Li DH, Chen MY. Serum adiponectin in breast cancer: A meta-analysis. Medicine (Baltimore) 2018; 97: e11433.

26. Ma HQ, Cui LH, Li CC, Yu Z, Piao JM. Effects of Serum Triglycerides on prostate cancer and breast cancer risk: a meta-analysis of prospective studies. Nutr Cancer 2016; 68: 1073-82.

27. Li X, Liu Z, Wu H, Dai W, Arshad B, Xu Z, et al. Status of lipid and lipoprotein in female breast cancer patients at initial diagnosis and during chemotherapy. Lipids Health Dis 2018; 17: 91. 